\title{
MENGUAK POTENSI ZAKAT DI KABUPATEN INDRAGIRI HILIR
}

\author{
Zuraidah dan Irdamisraini
}

\section{Dosen Fakultas Syariah dan Hukum UIN Suska Riau}

Email: zuraidah@uin-suska.ac.id

\begin{abstract}
Abstrac
The potential of Zakat in Indonesia is very large, as well as in Indragiri Hilir Regency. The potential of zakat in this area from the agriculture, plantation, livestock and fisheries sector is estimated to amount to \pm Rp. 270.2 Billion). Especially if added to the trade and mining sectors, services, as well as wealth zakat from individuals who have always liked to pay their zakat directly to mustahik, as well as zakat fitrah and zakat mal collected by amil-amil in mosques or mushalla that have not was reported to BAZNAS. Until now, the new can be collected by BAZNAS Indragiri Hilir Regency only $0.85 \%$. Even so, most of them come from ASN profession zakat in Indragiri Hilir Regency.
\end{abstract}

Key Words : Potential, Zakat, Indragiri Hilir Regency

Abstrak

Potensi Zakat di Indonesia cukup besar sekali, begitu juga di Kabupaten Indragiri Hilir. Potensi zakat di daerah ini dari sector pertanian, perkebunan, peternakan dan perikanan saja diperkirakan berjumlah \pm Rp. 270,2 Milyar). Apalagi kalau ditambah sector perdagangan dan pertambangan, jasa, juga zakat harta kekayaan dari individu-individu masyarakat yang selama ini masih suka membayarkan zakatnya langsung kepada mustahik, serta zakat fitrah maupun zakat mal yang dikumpulkan oleh amil-amil di masjid atau mushalla yang selama ini tidak pernah dilaporkan ke BAZNAS. Sampai saat ini, yang baru bisa dikumpulkan oleh BAZNAS Kabupaten Indragiri Hilir baru 0,85\% saja. Itupun sebagian besarnya bersumber dari zakat profesi ASN yang ada di Kabupaten Indragiri Hilir.

Kata kunci: Potensi, Zakat, Kabupaten Indragiri Hilir 


\section{Pendahuluan}

Zakat adalah ibadah yang mengandung dua dimensi; dimensi hablum minallah atau dimensi vertical dan dimensi hablum minannas atau dimensi horizontal. Ibadah zakat bila ditunaikan dengan baik, akan meningkatkan kualitas keimanan, membersihkan dan menyucikan jiwa, dan mengembangkan serta memberkahkan harta yang dimiliki. Jika dikelola dengan baik dan amanah, zakat akan mampu meningkatkan kesejahteraan umat, mampu meningkatkan etos dan etika kerja umat, serta sebagai institusi pemerataan ekonomi.

Potensi zakat di Indonesia sebenarnya cukup besar sekali, jika saja itu bisa dikelola dengan baik. Berdasarkan hasil penelitian BAZNAS dan IPB pada tahun 2011 saja potensi zakat di Indonesia bisa mencapai Rp. 217 Triliyun, namun yang baru bisa terkumpul hanya 0,8 persen yaitu Rp. 1,73 Triliyun. ${ }^{1}$ Salah satu penyebabnya adalah belum terkumpulnya zakat secara optimal di lembaga-lembaga pengumpul zakat. Hal ini disebabkan karena pengetahuan masyarakat terhadap harta yang wajib dikeluarkan zakatnya masih terbatas pada sumber-sumber konvensional yang secara jelas dinyatakan dalam Al-Qur'an dan Hadits dengan persyaratan tertentu. ${ }^{2}$ Di samping itu juga masih adanya sebagian masyarakat yang lebih suka menyalurkan zakat secara langsung kepada para asnaf bukan melalui amil atau lembaga pengelola zakat, serta masih adanya sebagian masyarakat yang menganggap lebih afdol jika berzakat kepada guru ngaji, para ustadz atau kiayi.

Demikian juga halnya yang terjadi di Kabupaten Indragiri Hilir. Indragiri Hilir merupakan salah satu Kabupaten dengan wilayah terluas di Propinsi Riau, terletak di pantai Timur pulau Sumatera, merupakan gerbang selatan Propinsi Riau, dengan luas daratan 11.605,97 $\mathrm{km}^{2}$ dan peraiaran 7.207 $\mathrm{Km}^{2}$ berpenduduk kurang lebih 694.614 jiwa yang terdiri dari berbagai etnis, Indragiri Hilir yang sebelumnya dijuluki ”Negeri Seribu Parit” yang sekarang terkenal dengan julukan "NEGERI

1 http://www.dakwatuna.com/2013/04/02/30417/potensi-zakat-umat-islam-di-indonesiabelum-dioptimalkan/\#ixzz454qc3jH3 diakses pada tanggal 6 April 2016.

${ }^{2}$ Didin Hafidhuddin, Zakat dalam Perekonomian Modern, (Jakarta: Gema Insani Press, 2002), hal. 2. 
SERIBU JEMBATAN" dikelilingi perairan berupa sungai-sungai besar dan kecil, parit, rawa-rawa dan laut, secara fisiografis. ${ }^{3}$

Sebagai sebuah daerah yang subur, Kabupaten Indragiri Hilir kaya akan sumber daya alam baik dalam bidang perkebunan terutama kelapa local, kelapa hibrida, kelapa sawit, karet, kopi, cokelat dan pinang. Dengan potensi tersebut membuat Kabupaten Indragiri Hilir tercatat sebagai salah satu daerah kelapa terbesar di Dunia, bahkan dijuluki sebagai "Tanah Hamparan Kelapa Dunia". 4 Demikian juga sector lainnya seperti pertanian dan holtikultura, perikanan, industry, pertambangan dan energy, perdagangan, jasa, dan sebagainya.

Dengan kekayaan sumber daya alam yang melimpah tersebut, maka potensi zakat di Kabupaten Indragiri Hilir sangat besar sekali, apalagi mayoritas penduduknya beragama Islam, bahkan daerah ini terkenal sebagai daerah yang kehidupan masyarakatnya sangat religious. Namun sayangnya potensi yang sangat besar tersdebut belum dikelola dengan baik. Meskipun BAZNAS Kabupaten Indragiri Hilir sudah ada, namun yang tergarap oleh BAZNAS baru sebatas zakat penghasilan yang bersumber dari PNS, yang saat ini baru mencapai 2,3 M dari target sebesar $5 \mathrm{M}^{5}$

Berdasarkan fenomena-fenomena di atas, maka perlu dilakukan suatu kajian yang mendalam tentang Potensi Zakat di Kabupaten Indragiri Hilir. Sehingga akan terlihat dengan jelas bagaimana potensi zakat di Kabupaten Indragiri Hilir, bagaimana upaya BAZNAS Kabupaten Indragiri Hilir dalam menggali potensi zakat, dan Apa saja kendala-kendala yang dihadapi BAZNAS dalam upaya menggali potensi zakat di Kabupaten Indragiri Hilir.

\section{Pengertian Menguak dan Potensi}

${ }^{3}$ http://www.inhilkab.go.id/index.php/en/pages/kondisi-umum, diakses pada tanggal 6 April 2016.

${ }^{4}$ Ibid.

${ }^{5}$ http://pusat.baznas.go.id/berita-utama/pemerintah-indragiri-hilir-terapkan-zakat-viapayroll-system/Skip to main content diakses pada tanggal 7 April 2016. 
Menguak berasal dari kata "kuak" yang berarti menjadi terbuka (tersibak, terungkap); dan membuka. ${ }^{6}$ Sedangkan Potensi berasal dari bahasa Inggris to potent yang berarti keras, kuat. Istilah lain potensi adalah kemampuan, kekuatan, kesanggupan atau daya baik sudah terwujud atau belum terwujud. Menurut kamus umum Bahasa Indonesia potensi berarti kemampuan yang mempunyai kemungkinan untuk dikembangkan. ${ }^{7}$

Berdasarkan pengertian di atas potensi merupakan daya yang dimiliki oleh setiap manusia. Hanya saja, daya itu belum terwujud atau belum dimanfaatkan secara maksimal. Dalam penjelasan di atas telah disinggung bahwa manusia dianugerahi cipta, rasa,dan karsa.

Udo Yamin Efendi Majdi (2007: 86) menjelaskan, kata potensi itu adalah serapan dari bahasa Inggris: potencial. Artinya ada dua kata, yaitu, (1) kesanggupan; tenaga (2) dan kekuatan; kemungkinan.Sedangkan menurut kamus besar bahasa Indonesia, definisi potensi adalah kemampuan yang mempunyai kemungkinan untuk dikembangkan, kekuatan, kesanggupan, daya.Intinya, secara sederhana, potensi adalah sesuatu yang bisa kita kembangkan. ${ }^{8}$

Menurut Slamet Wiyono(2006:37) potensi dapat diartikan sebagai kemampuan dasar dari sesuatu yang masih terpendam didalamnya yang menunggu untuk diwujudkan menjadi sesuatu kekuatan nyata dalam diri sesuatu tersebut. Menurut Endra K (2004: 6) potensi bisa disebut sebagai kekuatan, energi, atau kemampuan yang terpendam yang dimiliki dan belum dimanfaatkan secara optimal. Sedangkan Sri Habsari (2005: 2) menjelaskan, potensi diri adalah kemampuan dan kekuatan yang dimiliki oleh seseorang baik fisik maupun mental dan mempunyai kemungkinan untuk dikembangkan bila dilatih dan ditunjang dengan sarana yang baik. $^{9}$

${ }^{6}$ http://artikata.com/arti-336589-kuak.html diakses pada tanggal 6 April 2016.

${ }^{7}$ https://www.facebook.com/GudangIlmu/posts/438713016274464.\%202014 diakses pada tanggal 6 April 2016.

${ }^{8}$ http://cafemotivasi.com/pengertian-potensi-diri/ diakses pada tanggal 6 April 2016.

${ }^{9}$ Ibid. 
Dari pengertian di atas dapat disimpulkan bahwa Potensi dapat diartikan sebagai kemampuan dasar dari sesuatu yang masih terpendam didalamnya yang menunggu untuk diwujudkan menjadi sesuatu kekuatan nyata dalam diri sesuatu tersebut. Jadi Menguak Potensi berarti Mengungkap atau membuka kemampuan dasar dari sesuatu yang masih terpendam yang menunggu untuk diwujudkan menjadi sesuatu kekuatan nyata. Dalam hal ini yang akan diungkap adalah potensi zakat yang luar biasa besarnya yang jika dikelola secara optimal mampu mengentaskan kemiskinan dan meningkatkan kesejahteraan masyarakat.

\section{Pengertian Zakat}

Zakat menurut bahasa mempunyai beberapa arti, yaitu albarakatu "keberkahan", al-namaa "tumbuh dan berkembang", aththaharatu "kesucian", dan ash-shalahu "keberesan". ${ }^{10}$ Sedangkan secara istilah, meskipun para ulama mengemukakannya dengan redaksi yang agak berbeda antara satu dan lainnya, akan tetapi pada prinsipnya sama, yaitu bahwa zakat adalah bagian dari harta dengan persyaratan tertentu, yang Allah SWT mewajibkan kepada pemiliknya, untuk diserahkan kepada yang berhak menerimanya, dengan persyaratan tertentu pula. ${ }^{11}$

Hubungan antara zakat menurut bahasa dengan pengertian zakat menurut istilah, sangat nyata dan erat sekali, yaitu bahwa harta yang dikeluarkan zakatnya akan menjadi berkah, tumbuh, berkembang dan bertambah, suci dan beres (baik). Hal ini sebagaimana dinyatakan dalam surat at-Taubah ayat 103 :

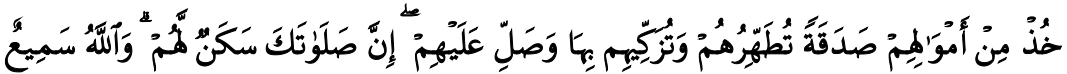
I hal. 396.

${ }^{10}$ Majma Lughah al-Arabiyyah, al-Mu'jam al-Wasith, (Mesir: Daar al-Ma'arif, 1972), Juz ${ }^{11}$ Ibid. 
"Ambillah zakat dari sebagaian harta mereka, dengan zakat itu kamu membersihkan dan menyucikan mereka, dan mendoalah untuk mereka. Sesungguhnya doa kamu itu menjadi ketentraman jiwa buat mereka. Dan Allah Maha Mendengar lagi Maha Mengetahui." (Q.S. At-Taubah : 103)

Dan surah ar-Ruum ayat 39 :

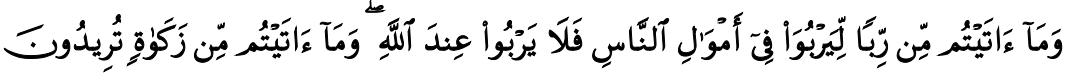

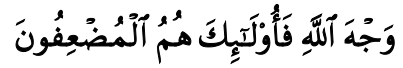

"Dan sesuatu riba (tambahan) yang kamu berikan agar dia bertambah pada harta manusia, maka riba itu tidak menambah pada sisi Allah. Dan yang kamu berikan berupa zakat yang kamu maksudkan untuk mencapai keridhaan Allah, maka (yang berbuat demikian) itulah orang-orang yang melipatgandakan hartanya." (Q.S. Ar-Ruum : 39)

Yang dimaksud dengan shadaqah dalam ayat di atas, adalah zakat, karena istilah shadaqah merupakan suatu konsep yang mempunyai nilai zakat itu sendiri dan karena tujuan mengeluarkan shadaqah itu untuk mentazkiyah-kan harta dan jiwa orang yang memberikannya (muzakki).

Ayat di atas berkenaan tentang zakat, tapi diungkapkan dengan istilah shadaqah. Namun dalam penggunaan sehari-hari orang sering lupa bagaimana pengertian yang sesungguhnya. Pengertian tersebut dapat juga dilihat dalam sebuah hadits yang diriwayatkan oleh Imam Bukhari dari Abu 'Ashim al-Dhahhak ibn Makhlad dari Zakaria 'ibn Ishaq dari Yahya ibn Abdillah ibn Shafiy ibn Ma'bad dari ibn Abbas r.a. Bahwa Nabi SAW mengutus Mu'az ke Yaman dan bersabda:

"Ajaklah mereka bersyahadah bahwa tiada Tuhan selain Allah, dan saya adalah Rasul Allah. Jika mereka patuh, terangkan pada mereka bahwa Allah memfardhukan shalat lima waktu sehari semalam daan jika mereka mentaatinya terangkan kepada mereka bahwa Allah mewajibkan shadaqah atas mereka yang kaya dan dibagikan kepada orang-orang faqir di kalangan mereka." 12 
Dari penjelasan di atas, dapat diambil kesimpulan bahwa zakat adalah sarana atau tali pengikat yang kuat dalam mengikat hubungan vertikal antara muzakki dan Tuhan serta hubungan horizontal antara sesama manusia khususnya antara yang kaya dengan yang miskin dan saling memberikan keuntungan moril maupun materiil, baik dari pihak penerima (mustahik) dan dari pihak pemberi (muzakki).

\section{Tujuan Zakat}

Kitab-kitab fiqh klasik membahas masalah zakat, hanya konsentrasi dalam hal ibadah, juga dari sei substansi hukumnya dan aspek eskatologis, tanpa mengemukakan secara jelas urgensi dan tujuannya, sehingga konsep zakat belum dipahami secara utuh sebagai suatu sistem yang mengandung berbagai nilai. ${ }^{13}$ Begitu juga dengan tujuan zakat itu sendiri, bukan hanya untuk mengumpulkan harta dan memenuhi kas dan bukan pula sekedar untuk menolong orang yang lemah ekonominya, tetapi tujuan yang paling dominan adalah agar manusia lebih tinggi nilainya dari pada harta, sehingga ia tidak menjadai budak harta. Maka tujuan zakat bagi muzakki sama dengan kepentingannya bagi penerima. Dalam al-Quran dijelaskan tujuan zakat, untuk membersihkan (tathhir) dan mensucikan (tazkiyah). Yusuf al-Qardhawi membagi tujuan zakat kepada tiga bagian, yaitu dari pihak muzakki, pihak penerima (mustahik) dan dampaknya dalam kehidupan bermasyarakat.

\section{Tujuan Zakat Bagi Muzakki}

Dari pihak muzakki, mengeluarkan zakat semata-mata karena Allah dan mencari ridha-Nya akan suci dari segala kotoran dosa, terutama sifat kikir yang merupakan sifat dan watak manusia. Zakat menghilangkan tabi'at dan watak

${ }^{12}$ Ibn Hajar al-Asqalani, Fath al-Bari bi Syarh Shahih al-Bukhari, Juz, III, (Kairo: Dar alRayyan at-Turats, tt), hal. 307.

${ }^{13}$ Yusuf Qardhawi, Fiqh al-Zakat, Muasasah al-Risalah, op.cit, hal. 9-14. 
tersebut, manusia akan terlepas dari perbudakan harta dan cinta dunia dan hanya menjadi hamba Allah semata.

Tujuan zakat juga mendidik seorang Muslim untuk berinfaq dan memberi dengan ikhlas. Suatu kebiasaan memberi mendatangkan efek yang mendalam terhadap jiwa, sifat dan akhlak yang utama bagi dirinya. Sifat itu tumbuh bersama ridha Allah dan memberi jalan yang mudah. Tujuan zakat bagi muzakki juga untuk berakhlak dengan sifat Tuhan yang Maha memberi kebaikan, rahmat dan kasih sayang. Zakat merupakan manifestasi syukur atas rahmat Allah dan mengembangkan kekayaan bathin serta menarik rasa senang atau simpati, sehingga tidak ada jurang pemisah antara orang kaya dengan orang miskin.

\section{Tujuan Zakat Bagi Mustahiq}

Tujuan zakat bagi mustahiq adalah membebaskan mereka dari masalahmasalah perekonomian, karena zakat dapat memberi jalan keluar dalam kesulitan hidup dan mengangkat martabat mereka. Tujuan ini baru dapat tercapai apabila para muzakki menyalurkan zakatnya melalui lembaga amil zakat baik yang dikelola oleh pemerintah maupun oleh pihak swasta.

Tujuan lain adalah membersihkan hati para mustahiq dari sikap dengki dan benci (kecemburuan sosial) terhadap orang yang berada atau kaya. Dengan demikian akan timbul rasa persaudaraan antar sesama, secara tidak langsung juga akan menimbulkan rasa aman, tenteram dan saling menjaga.

\section{Tujuan Zakat Dalam Kehidupan Sosial}

Tujuan zakat dilihat dari kepentingan sosial adalah merealisasikan fungsi harta sebagai alat perjuangan menegakkan agama Allah dan mewujudkan keadilan sosial ekonomi masyarakat pada umumnya. ${ }^{14} \mathrm{Di}$ samping itu juga untuk menjembatani jurang pemisah antara yang kaya dengan yang miskin dalam suatu

${ }^{14}$ Ibid, hal. 856-884. 
masyarakat, serta sebagai sarana pemerataan pendapatan (rezeki) untuk mencapai keadilan sosial. ${ }^{15}$

Sasaran pendistribusian zakat terhadap para muallaf dan fi sabilillah, menunjukkan adanya strategi agama yang bersifat sosial politik. Zakat merupakan jaminan sosial dalam Islam. Islam memperkenalkan aturan ini dalam ruang lingkup yang lebih luas, mencakup segi kehidupan material dan spritual, seperti jaminan akhlak, pendidikan, politik, pertahanan, pidana, ekonomi, kebudayaan dan jaminan sosial.

Dari sisi ekonomi, zakat meberi motivasi muzakki untuk mendistribusikan hartanya, dan kekayaan tidak terpendam atau bertumpuk pada orang kaya. Dengan pelaksanaan zakat diharapkan tegaknya hidup bermasyarakat, dapat membanagkitkan semangat individu dan nilai-nilai kemanusiaannya. Menyerahkan sesuatu yang bermanfaat bagi masyarakat dapat menolak keburukan, di samping juga bertujuan untuk memelihara akidah, fitrah manusia, pendidikan, serta memberikan pandangan kepada seseorang tentang hakikat, tujuan hidup dan kehidupan akhirat.

\section{Urgensi Manajemen Pengelolaan Zakat}

Pelaksanaan zakat didasarkan pada firman Allah dalam QS. At-Taubah:60

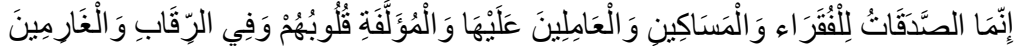

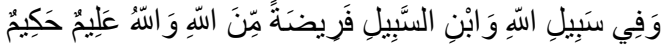

"Sesungguhnya zakat-zakat itu, hanyalah untuk orang-orang fakir, orangorang miskin, pengurus-pengurus zakat, para mu'allaf yang dibujuk hatinya, untuk (memerdekakan) budak, orang-orang yang berhutang, untuk jalan Allah dan untuk mereka yuang sedang dalam perjalanan, sebagai suatu ketetapan yang diwajibkan Allah, dan Allah Maha Mengetahui lagi Maha Bijaksana." 16 (QS. At-Taubah:60)

${ }^{15}$ Mohammad Daud Ali, Sistem Ekonomi Islam, Zakat dan Wakaf, (Jakarta: UI-Press, cet. I, 1988), hal. 40.

${ }^{16}$ Yang berhak menerima zakat ialah: 1 . Orang fakir: orang yang amat sengsara hidupnya, tidak mempunyai harta dan tenaga untuk memenuhi penghidupannya. 2. Orang miskin: orang yang tidak cukup penghidupannya dan dalam keadaan kekurangan. 3. Pengurus zakat: orang yang diberi tugas untuk mengumpulkan dan membagikan zakat. 4. Muallaf: orang kafir yang ada harapan masuk Islam dan orang yang baru masuk Islam yang imannya masih lemah. 5. Memerdekakan budak: mencakup juga untuk melepaskan 
Juga dalam firman Allah SWT QS. At-Taubah:103

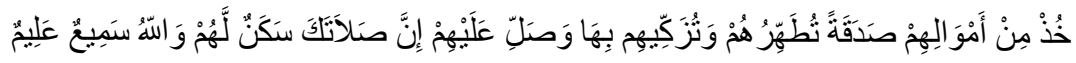

"Ambillah zakat dari sebagian harta mereka, dengan zakat itu kamu membersihkan ${ }^{17}$ dan mensucikan ${ }^{18}$ mereka dan mendo'alah untuk mereka. Sesungguhnya do'a kamu itu (menjadi) ketenteraman jiwa bagi mereka. Dan Allah Maha Mendengar lagi Maha Mengetahui.” (QS. At-Taubah:103)

Dalam surah At-taubah :60 dikemukakan bahwa salah satu golongan yang berhak menerima zakat adalah orang yang bertugas mengurus zakat ('amilina 'alaiha). Sedangkan dalam surah At-taubah:103 bahwa zakat itu diambil dari orang-orang yang berkewajiban untuk berzakat (muzakki) untuk kemudian diberikan kepada yang berhak menerimanya (mustahiq). Yang mengambil dan menjemput tersebut adalah para petugas ('amil). Imam Qurtubi ${ }^{19}$ menafsirkan surah At-Taubah : 60 menyatakan bahwa amil itu adalah orang yang ditugaskan oleh imam atau pemerintah untuk mengambil, menuliskan, menghitung dan mencatatkan zakat yang diambilnya dari muzakki untuk kemudian diberikan kepada yang berhak menerimanya. Karena itu Rasulullah SAW pernah mempekerjakan seorang dari suku Asad yang bernama ibnu lutaibah untuk mengurus urusan zakat Bani Sulaim. ${ }^{20}$ Begitu pula dengan Muas bin Jabal yang ditugaskan di negeri

muslim yang ditawan oleh orang-orang kafir. 6. Orang berhutang: orang yang berhutang karena untuk kepentingan yang bukan ma'siat dan tidak sanggup membayarnya. Adapun orang yang berhutang untuk memelihara persatuan umat Islam dibayar hutangnya itu dengan zakat, walaupun ia mampu membayarnya. 7 . Pada jalan Allah (sabilillah): yaitu untuk keperluan pertahanan Islam dan kaum muslimin. Di antara mufasirin ada yang berpendapat bahwa fisabilillah itu mencakup juga kepentingan-kepentingan umum seperti mendirikan sekolah, rumah sakit dan lain-lain. 8. Orang yang sedang dalam perjalanan yang bukan ma'siat mengalami kesengsaraan dalam perjalanannya.

${ }^{17}$ Maksudnya: zakat itu membersihkan mereka dari kekikiran dan cinta yang berlebih-lebihan kepada harta benda

18 Maksudnya: zakat itu menyuburkan sifat-sifat kebaikan dalam hati mereka dan memperkembangkan harta benda mereka.

${ }^{51}$ Al-Qurtubi, al-jami' Li Ahkam Al-qur'an, Beirut Libanon, Daar el-Kutub 'Ilmiyyah 1413 H/1993M Jilid VII-VIII, hlm, 112-113

${ }^{20}$ Ibid, hlm. 113 
Yaman sebagai da'i juga sebagai pengurus Zakat. Demikian pula yang dilakukan oleh para khulafaur rasyidin sesudahnya.

Zakat adalah kewajiban berdasarkan syari'at. Islam mewajibkan atas setiap Muslim yang sampai padanya nisab (batas minimal dari harta mulai wajib dikeluarkan) zakat. Zakat salah satu rukun Islam, bahkan merupakan rukun kemasyarakatan yang paling tampak di antara semua rukun-rukun Islam, sebab di dalam zakat terdapat hak orang banyak yang terpikul pada pundak individu. ${ }^{21}$

Zakat bukanlah merupakan urusan pribadi, yang berarti pelaksanaannya diserahkan kepada pribadi masing-masing, yang berarti pula tidak dapat dikenakan sanksi hukuman apa pun terhadap pribadi-pribadi wajib zakat yang enggan menunaikan zakat. Sebab sejak zaman Rasulullah saw, al-Khulafa' al-Rasyidin dan pemerintahan Islam sesudahnya telah dikelola dengan baik dan ditangani oleh aparat pemerintah, yang disebut Amil Zakat, dan kemudian membagikannya kepada yang berhak menerimanya. ${ }^{22}$ Di samping Amil Zakat ada lagi lembaga yang mempunyai tugas yang sama dengan Amil Zakat, Ialah Baitul Maal.

Dampak zakat sangat terasa sekali karena dapat mengikis habis sifat-sifat kikir di dalam jiwa seesorang, serta melatihnya memiliki sifat-sifat dermawan, dan mengantarkannya mensyukuri nikmat Allah, sehingga pada akhirnya ia dapat menyucikan diri dan mengembangkan pribadinya. ${ }^{23}$ Kedua, menciptakan ketenangan dan ketentraman, bukan hanya kepada penerima, tetapi juga kepada pemberi zakat itu. ${ }^{24}$

Dalam memungut dan menyalurkan zakat perlu suatu badan atau lembaga resmi, yang nantinya dapat bekerja secara maksimal dan dapat

${ }^{21}$ Lihat Yusuf Qardhawi, op.cit, Sayyid Sabiq, Fiqhus Sunnah, dan lihat juga Dr. Ahmad Muhammad al-'Assal dan Dr. Fathi Ahmad Abdul Karim, Sistem, Prinsip dan Tujuan Ekonomi Islam, (terj), (Bandung: Pustaka Setia, 1999), hal. 104.

${ }^{22}$ Mahfuz Zuhdi, Masailul Fiqhiyah, (Jakarta: CV. Haji Masagung, 1993), hal. 250.

${ }^{23}$ Quraish Shihab, Membumikan al-Qur'an, (Fungsi dan Peran Wahyu dalam Kehidupan Masyarakat), (Bandung: Mizan, 1994), hal. 25.

${ }^{24}$ Ibid. 
dipertanggungjawabkan. Rasyid Ridha ${ }^{25}$ dan Yusuf Qardhawi ${ }^{26}$ menghendaki agar para Amil Zakat atau Baitul Maal diatur dan dikelola oleh Pemerintah, karena ada keistimewaan kebijaksanaan tersebut, antara lain:

1. Jaminan terlaksananya syariat zakat (karena ada saja manusia-manusia yang berusaha menghindar bila tidak diawasi oleh penguasa).

2. Pemerataan (karena keterlibatan satu tangan, diharapkan pula semua mustahiq akan memperoleh bagiannya).

3. Memelihara air muka para mustahiq, karena mereka tidak perlu berhadapan langsung dengan para muzakki, dan mereka tidak harus pula datang meminta.

4. Sektor (ashnaf yang harus menerima) zakat, tidak terbatas pada individu, tetapi juga untuk kemashlahatan umum, dan sektor ini hanya dapat ditangani oleh pemerintah.

Menurut Abdurrahman Qadir, Pengelolaan zakat oleh lembaga pengelola zakat memiliki beberapa keuntungan antara lain: ${ }^{27}$

Pertama, untuk menjamin kepastian dan disiplin pembayaran zakat.

Kedua, untuk menjaga perasaan rendah diri para mustahik zakat apabila berhadapan langsung untuk menerima zakat dari para muzakki.

Ketiga, untuk mencapai efisiensi dan efektifitas serta sasaran yang tepat dalam penggunaan harta zakat menurut skala proritas yang ada pada suatu tempat.

Keempat, untuk memperlihatkan syiar islam dalam semangat penyelenggaraan pemerintahan yang Islami.

Kelima, untuk memudahkan kordinasi dan konsolidasi data muzakki dan mustahiq. Keenam, untuk memudahkan pelaporan dan pertanggungjawaban ke publik.

\footnotetext{
${ }^{25}$ Rasyid Ridha, Tafsir al-Manar, op.cit, hal. 513.

${ }^{26}$ Yuusuf Qardhawi, log.cit.

${ }^{27}$ Abdurrahman Qadir, Zakat dalam Dimensi Mahdah dan Sosial, (Jaakarta: Raja Grafindo Persada, ,
} 1988). Hal. 85 
Ketujuh, agar pengelolaaannya dapat dikelola secara professional (pen). Sebaliknya jika zakat diserahkan langsung dari muzakki ke mustahik, meskipun secara hukum syar'i adalah sah, akan tetapi disamping akan terabaikannya hal-hal tersebut diatas, juga hikmah dan fungsi zakat, terutama yang berkaitan dengan pemerataan dan kesejahteraan ummat, akan sulit diwujudkan.

Di Indonesia, pengelolaan zakat diatur berdasarkan Undang-undang No. 38 tahun 1999 tentang Pengelolaan Zakat dengan Keputusan Menteri Agama (KMA) No. 581 tahun 1999 tentang Pelaksanaan Undang-undang No. 38 tahun 1999 dan Keputusan Direktur Jenderal Bimbingan Masyarakat Islam dan Urusan Haji No. D / 291 tahun 2000 tentang Pedoman Teknis Pengelolaan Zakat sebagaimana diubah dengan Undang-undang No. 23 tahun 2011 tentang Pengelolaan Zakat dan PP No. 14 tahun 2014 tentang Pelaksanaan Undang-undang No. 23 Tahun 2011 tentang Pengelolaan Zakat. Meskipun harus diakui bahwa dalam peraturan-peraturan tersebut masih banyak kekurangan yang sangat mendasar, misalnya tidak dijatuhkannya sanksi bagi muzakki yang melalaikan kewajibannya (tidak mau berzakat), tetapi undang-undang tersebut mendorong upaya pembentukan lembaga pengelola zakat yang amanah, kuat dan dipercaya oleh masyarakat.

Dalam Bab II Pasal 5 undang-undang tersebut dikemukakan bahwa pengelolaan zakat bertujuan:

1. Meningkatkan pelayanan bagi masyarakat dalam menunaikan zakat sesuai dengan tuntutan agama.

2. Meningkatkan fungsi dan peranan pranata keagamaan dalam upaya mewujudkan kesejahteraan masyarakat dan keadilan sosial.

3. Meningkatkan hasil guna dan daya guna zakat. ${ }^{28}$ Selanjutnya, dalam Bab III Undang-undang No. 38 tahun 1999 dikemukakan bahwa organisasi pengelola zakat terdiri dari dua jenis, yaitu Badan

${ }^{28}$ Undang-undang Republik Indonesia Nomor 38 tahun 1999 tentang Pengelolaan Zakat dan Keputusan Menteri Agama RI Nomor 581 tentang PelaksanaanUndang-undang Nomor 38 tahun 1999, (Jakarta: Direktorat Urusan Haji Departemen Agama RI, 1999). 
Amil Zakat (pasal 6) dan Lembaga Amil Zakat (pasal 7). Kemudian pada bab tentang sanksi (Bab VIII) dikemukakan pula bahwa setiap pengelola zakat yang karena kelalaiannya tidak mencatat atau mencatat dengan tidak benar tentang zakat, infak, sedekah, hibah, wasiat, waris dan kafarat, sebagaimana yang dimaksud dalam pasal 8, pasal 12 dan pasal 11 undang-undang tersebut, diancam dengan hukuman kurungan selama-lamanya tiga bulan dan/atau denda sebanyak-banyaknya Rp. 30.000.000 (tiga puluh juta rupiah). Sanksi ini tentu dimaksudkan agar BAZ dan LAZ yang ada di negara kita menjadi pengelola zakat yang kuat, amanah, dan dipercaya oleh masyarakat, sehingga pada akhirnya masyarakat secara sadar dan sengaja akan menyerahkan zakatnya kepada lembaga pengelola zakat.

\section{Metode Penelitian}

Metode penelitian yang digunakan adalah metode analisis kualitatif deskriptif. yaitu upaya menghimpun data, mengelola dan menganalisis secara kualitatif dan menafsirkan secara kualitatif pula. ${ }^{29}$ Pengelolaan data kualitatif langsung dikerjakan di lapangan dengan mencatat dan mendeskripsikan gejalagejala sosial yang dihubungkan dengan gejala lain.

Dalam melaksanakan penelitian ini, peneliti menggunakan jenis penelitian kualitatif dengan metode analisis deskriptif kualitatif. Alasan peneliti memilih metode deskriptif kualitatif adalah:

1. Penelitian ini bertujuan untuk menguak atau mengungkap potensi zakat yang ada di Kabupaten Indragiri Hilir.

2. Untuk memperoleh data yang akurat, di samping mengumpulkan data-data sekunder, peneliti merasa perlu untuk melakukan wawancara dengan pengurus BAZNAS Kabupaten Indragiri Hilir. ${ }^{30}$

\footnotetext{
${ }^{29}$ Wardi Bachtiar, Metode Penelitian Ilmu Dakwah, (Jakarta: Logos, 1997) hlm. 23.

${ }^{30}$ Dalam melakukan sebuah penelitian banyak macam metode penelitian yang dapat digunakan.Namun demikian, metode penilitian yang dipilih hendaknya disesuaikan dengan masalah, tujuan dan kegunaan dari penelitian itu sendiri.
} 
Penelitian ini menggunakan pendekatan kualitatif yaitu pendekatan yang digunakan untuk mendeskripsikan, menggambarkan atau melukiskan secara sistematis, faktual dan akurat tentang fakta-fakta serta sifat hubungan antara fenomena yang diselidiki. Karena obyek penelitian ini adalah menguak potensi zakat, sehingga akan lebih tepat menggunakan penelitian kualitatif.

Menurut Moleong, mengutip pendapatnya Bogdan dan Taylor, metodologi kualitatif adalah suatu prosedur penelitian yang menghasilkan data deskriptif berupa kata-kata tertulis atau lisan dari orang-orang dan perilaku yang dapat diamati. $^{31}$

Jenis penelitian yang digunakan dalam penelitian ini adalah jenis penelitian deskriptif artinya melukiskan variabel demi variabel, satu demi satu. Menurut Hasan, metode deskriptif bertujuan untuk:

1. Mengumpulkan informasi aktual secara rinci yang melukiskan gejala yang ada.

2. Mengidentifikasi masalah/memeriksa kondisi dan praktek-praktek dan rutinitas yang berlaku.

3. Membuat perbandingan dan evaluasi.

4. Menentukan apa yang dilakukan orang lain dalam menghadapi masalah yang sama dan belajar dari pengalaman mereka untuk menetapkan rencana dan keputusan yang akan datang. ${ }^{32}$

5

\section{Subjek dan Objek Penelitian}

a. Sebagai subjek penelitian adalah pengurus BAZNAS Kabupaten Indragiri Hilir.

b. Objek penelitian adalah Menguak Potensi Zakat di Kabupaten Indragiri Hilir.

${ }^{31}$ Lihat: Lexy J. Moleong, Metodologi Penelitian Kualitatif edisi revisi cet.21, (Bandung: Remaja Rosdakarya, 2005.)

${ }^{32}$ Hasan, M. Iqbal, Pokok-pokok Materi Metodologi Penelitian dan Aplikasinya. (Jakarta: Bumi Aksara, 2002) 


\section{Populasi dan Sampel}

Populasi dalam penelitian ini adalah pengurus BAZNAS Kabupaten Indragiri Hilir. Karena jumlahnya terjangkau, maka semuanya dijadikan sampel dengan menggunakan metode total sampling..$^{33}$ yaitu pengambilan sampel secara keseluruhan sesuai dengan kepentingan dan tujuan penelitian.

\section{Lokasi dan Waktu Penelitian}

Penelitian ini dilaksanakan di Kabupaten Indragiri Hilir. Alasan penulis memilih lokasi ini karena penulis melihat potensi zakat yang luar biasa di daerah ini, namun belum dikelola secara optimal.

Waktu penelitian dilaksanakan selama lebih kurang enam bulan yang dimulai terhitung dari Juni dan selesai November 2016.

\section{Sumber Data}

Penelitian ini mengambil data yang bersumber dari data primer dan data skunder. Data primer yaitu data yang langsung diperoleh dari lapangan baik melalui observasi, maupun wawancara dengan pengurus BAZNAS Kabupaten Indragiri Hilir. Sedangkan data sekunder adalah data-data penunjang peneltian ini, didapatkan dari sumber lainnya dari berbagai informasi, seperti buku-buku, data dari Badan Pusat Statistik (BPS) Kabupaten Indragiri Hilir, serta dokumentasi yang ada di BAZNAS Kabupaten Indragiri Hilir.

\section{Metode Pengumpulan Data}

Dalam penelitian ini digunakan teknik pengumpulan data observasi dan wawancara. Kedua metode tersebut dijelaskan sebagai berikut:

1. Observasi, yaitu pengambilan data yang dilakukan dengan cara melakukan pengamatan langsung kepada obyek penelitian dan dimaknai secara rasional.

${ }^{33}$ Nur Indriantoro \& Bambang Supomo, Metodologi Penelitian Bisnis, (Yogyakarta: BPFE-Yogyakarta,2002), Cet. Ke-2, h. 131. 
Peneliti melakukan pengamatan dan mencerna secara seksama setiap kegiatan pengumpulan zakat oleh BAZNAS Kabupaten Indragiri Hilir.

2. Wawancara adalah teknik pengumpulan data yang didasarkan pada percakapan secara intensif dengan suatu tujuan tertentu. Wawancara dilakukan untuk mendapatkan berbagai informasi menyangkut masalah yang diajukan dalam penelitian. Wawancara dilakukan kepada informan yang dianggap menguasai atau memahami masalah dalam penelitian ini, yaitu pengurus BAZNAS Kabupaten Indragiri Hilir tentang permasalahan yang diteliti.

3. Dokumentasi yaitu dengan melihat dan menganalisa dokumen-dokumen dan buku-buku yang berkaitan dengan penelitian.

\section{Teknik Analisa Data}

Teknik analisis data adalah menggunakan data deskriptif untuk memperoleh gambaran tentang Potensi zakat di Kabupaten Indragiri Hilir, upaya BAZNAS Kabupaten Indragiri Hilir dalam meningkatkan pengumpulan zakat, serta kendalakendala yang dihadapi BAZNAS dalam upaya meningkatkan pengumpulan zakat di Kabupaten Indragiri Hilir. Kegiatan akhir dari penelitian menulis laporan, yaitu penulisan laporan merupakan bagian analisa kualitatif yang tidak terpisahkan. Dalam laporan ini peneliti berusaha menulis kata, frase dan kalimat serta pengertian secara tepat yang dapat digunakan untuk mendeskripsikan data dan hasil analisisnya. Laporan diwujudkan dalam bentuk narasi yang menjelaskan hasil analisis data yang diteliti yang didukung oleh data atau informasi yang telah dikumpulkan.

\section{Hasil Penelitian dan Pembahasan}

\section{Potensi Zakat di Kabupaten Indragiri Hilir}

Kabupaten Indragiri Hilir terletak di pantai Timur pulau Sumatera, merupakan gerbang selatan Propinsi Riau, dengan luas daratan 11.605,97 km² dan peraiaran $7.207 \mathrm{Km}^{2}$ berpenduduk kurang lebih 694.614 jiwa yang terdiri dari 
berbagai etnis, Indragiri Hilir yang sebelumnya dijuluki "Negeri Seribu Parit” yang sekarang terkenal dengan julukan "NEGERI SERIBU JEMBATAN" dikelilingi perairan berupa sungai-sungai besar dan kecil, parit, rawa-rawa dan laut, secara fisiografis Kabupaten Indragiri Hilir beriklim tropis merupakan sebuah daerah dataran rendah yang terletak diketinggian 0-4 meter di atas permukaan laut dan dipengaruhi oleh pasang surut.

Sebagai sebuah daerah yang subur, Kabupaten Indragiri Hilir kaya akan sumber daya alam baik dalam bidang perkebunan terutama kelapa local, kelapa hibrida, kelapa sawit, karet, kopi, cokelat dan pinang. Dengan potensi tersebut membuat Kabupaten Indragiri Hilir tercatat sebagai salah satu daerah kelapa terbesar di Dunia, bahkan dijuluki sebagai "Tanah Hamparan Kelapa Dunia". ${ }^{4}$ Demikian juga sector lainnya seperti pertanian dan holtikultura, perikanan, industry, pertambangan dan energy, perdagangan, jasa, dan sebagainya.

Berdasarkan data dari Badan Pusat Statistik Kabupaten Indragiri Hilir, hasil produksi pertanian dan perkebunan di Kabupaten Indragiri Hilir tahun 2014, yaitu:

Tabel 1

Hasil Produksi Pertanian di Kabupaten Indragiri Hilir tahun 2014

\begin{tabular}{|r|l|r|r|}
\hline No & \multicolumn{1}{|c|}{ Jenis Pertanian } & \multicolumn{1}{|c|}{$\begin{array}{c}\text { Luas (ha) } \\
\text { (ton) }\end{array}$} \\
\hline 1 & Padi Sawah & 25,188 & 96.672 .12 \\
\hline 2 & Padi Ladang & 439 & 1.103 .21 \\
\hline 3 & Jagung & 1,595 & $2.974,97$ \\
\hline 4 & Kedelai & 74 & 85,46 \\
\hline 5 & Kacang Tanah & 18 & 18,01 \\
\hline 6 & Kacang Hijau & 39 & 40,86 \\
\hline 7 & Ubi Kayu & 241 & $6.646,21$ \\
\hline 8 & Ubi Jalar & 100 & 825.01 \\
\hline \multicolumn{2}{r|}{ Total } & $\mathbf{2 7 . 6 9 4}$ & $\mathbf{1 0 8 . 3 6 5 . 8 5}$ \\
\hline
\end{tabular}

${ }^{34}$ Ibid. 
Sumber: Data BPS Kab INHIL 2016

Tabel 2

Hasil Produksi Perkebunan di Kabupaten Indragiri Hilir 2014

\begin{tabular}{|c|c|c|c|c|}
\hline No & Jenis Perkebunan & Luas (ha) & $\begin{array}{l}\text { Hasil Produksi } \\
(\mathrm{kg})\end{array}$ & Jumlah Petani \\
\hline 1 & Kelapa Dalam/Lokal & 381.617 & 566.755 .865 & 78.007 \\
\hline 2 & Kelapa Hibrida & 37.346 & 40.663 .961 & 15.120 \\
\hline 3 & Kelapa Sawit & 109.023 & 249.518 .344 & 79.458 \\
\hline 4 & Karet & 5.368 & 3.924 .240 & 1.700 \\
\hline 5 & Sagu & 17.933 & 7.408 .798 & 1.893 \\
\hline 6 & Nipah & 12.807 & 896.702 & 1.296 \\
\hline 7 & Kopi & 1.240 & 292.571 & 1.038 \\
\hline 8 & Kakao & 1.890 & 322.943 & 379 \\
\hline 9 & Pinang & 16.407 & 7.629 .093 & 15.592 \\
\hline & Total & 583.631 & 877.412 .517 & 194.483 \\
\hline
\end{tabular}

Sumber: Data BPS Kab INHIL 2016

Sedangkan hasil peternakan dan perikanan di Kabupaten Indragiri Hilir tahun 2014, yaitu:

Tabel 3

Hasil Produksi Peternakan di Kabupaten Indragiri Hilir 2014

\begin{tabular}{|c|l|r|}
\hline No & Jenis Peternakan & Jumlah (ekor) \\
\hline 1 & Sapi & 6.680 \\
\hline 2 & Kambing & 18.977 \\
\hline 3 & Domba & 399 \\
\hline \multicolumn{2}{|c|}{ Total } & $\mathbf{2 6 . 0 5 6}$ \\
\hline
\end{tabular}

Sumber: Data BPS Kab INHIL 2016

Tabel 4

Hasil Produksi Perikanan Tangkap di Kabupaten Indragiri Hilir 2014 


\begin{tabular}{|c|lr|r|}
\hline No & Jenis Perikanan & Jumlah Produksi (ton) \\
\hline 1 & Laut & $42.692,82$ \\
\hline 2 & Umum & $7.694,07$ \\
\hline 3 & Kolam & 456,90 \\
\hline 4 & Tambak & $3.301,50$ \\
\hline \multicolumn{2}{r|}{ Total } & $\mathbf{5 4 . 1 4 5 , 2 9}$ \\
\hline
\end{tabular}

Sumber: Data BPS Kab INHIL 2016

Berdasarkan data-data di atas, maka diperkirakan potensi zakat dari sector pertanian 271 Milyar, perkebunan 220 Milyar, peternakan 4 Milyar, dan perikanan 203 Milyar atau totalnya 698 Milyar. Jumlah ini belum termasuk sector perdagangan dan pertambangan, jasa, juga zakat harta kekayaan dari individuindividu masyarakat yang selama ini masih suka membayarkan zakatnya langsung kepada mustahik, serta zakat fitrah maupun zakat mal yang dikumpulkan oleh amilamil di masjid atau mushalla yang selama ini tidak pernah dilaporkan ke BAZNAS, jumlahnya tentu lebih besar lagi. Menurut perkiraan penulis, bisa lebih dari 1 triliyun rupiah.

Dengan kekayaan sumber daya alam yang melimpah tersebut, maka potensi zakat di Kabupaten Indragiri Hilir sangat besar sekali, apalagi mayoritas penduduknya beragama Islam, bahkan daerah ini terkenal sebagai daerah yang kehidupan masyarakatnya sangat religious. Namun sayangnya potensi yang sangat besar tersdebut belum dikelola dengan baik. Meskipun BAZNAS Kabupaten Indragiri Hilir sudah ada, namun yang tergarap oleh BAZNAS baru sebatas zakat penghasilan yang bersumber dari PNS yang berjumlah 8.023 orang, yang saat ini baru mencapai 2,3 $\mathrm{M}$ dari target sebesar $5 \mathrm{M} .^{35}$

\section{Upaya BAZNAS Kabupaten Indragiri Hilir dalam menggali potensi zakat}

${ }^{35}$ http://pusat.baznas.go.id/berita-utama/pemerintah-indragiri-hilir-terapkan-zakat-viapayroll-system/Skip to main content diakses pada tanggal 7 April 2016. 
Dari hasil wawancara penulis dengan Ketua BAZNAS Kabupaten Indragiri Hilir, upaya yang dilakukan BAZNAS dalam menggali potensi zakat di Kabupaten Indragiri Hilir baru sebatas bekerjasama dengan Pemerintah Daerah dalam memungut zakat penghasilan melalui Unit Pengumpul Zakat (UPZ) yang ada di Instansi-instansi Pemerintahan. ${ }^{36}$ Belum ada upaya untuk menggali potensi zakat yang lain selain zakat penghasilan. Di samping itu juga belum ada kerjasama dengan pihak lain seperti BUMN, BUMD, Perusahaan-perusahaan Swasta serta kalangan professional untuk menambah penerimaan zakat, infaq dan shadaqah.

\section{Kendala-kendala yang dihadapi BAZNAS dalam upaya menggali potensi zakat di Kabupaten Indragiri Hilir}

Berdasarkan hasil wawancara penulis dengan pengurus BAZNAS, ada beberapa kendala yang dihadapi mereka dalam upaya menggali potensi zakat di Kabupaten Indragiri Hilir yaitu: ${ }^{37}$

1. Masih ada PNS yang tidak mau dipotong gajinya dengan alasan gajinya sudah minus, masih banyak keperluan yang harus dipenuhi, dll.

2. Ada perusahaan yang dulunya pernah menyalurkan zakatnya ke BAZNAS sekarang tidak lagi dikarenakan berganti kepemilikan.

3. Masih kurangnya kesadaran masyarakat untuk membayarkan zakatnya ke BAZNAS.

4. Kondisi geografis Kabupaten Indragiri Hilir yang sangat luas serta jarak dari satu tempat ke tempat lain cukup jauh dan harus ditempuh melalui laut atau sungai.

5. Tidak adanya bantuan operasional dari Pemerintah Daerah, sehingga pengurus terpaksa hanya mengandalkan bagian dari amil.

${ }^{36}$ Drs. H. Syamsurizal Awi, MP, Ketua BAZNAS Kab. INHIL, Wawancara, Tembilahan tanggal 20 Oktober 2016.

${ }^{37}$ Fitri Yanti SE, Pengurus BAZNAS Kab. INHIL, Wawancara, Tembilahan 20 Oktober 2016 
6. Tidak adanya koordinasi dengan pihak terkait lainnya seperti Kementerian Agama, KUA, serta UPZ atau amil-amil yang ada di masjid-mesjid dan mushala.

\section{Kesimpulan}

Potensi zakat di Kabupaten Indragiri Hilir sangat besar sekali. Dari sector pertanian, perkebunan, peternakan dan perikanan saja diperkirakan berjumlah $\pm \mathrm{Rp}$. 270,2 Milyar). Apalagi kalau ditambah sector perdagangan dan pertambangan, jasa, juga zakat harta kekayaan dari individu-individu masyarakat yang selama ini masih suka membayarkan zakatnya langsung kepada mustahik, serta zakat fitrah maupun zakat mal yang dikumpulkan oleh amil-amil di masjid atau mushalla yang selama ini tidak pernah dilaporkan ke BAZNAS, jumlahnya tentu lebih besar lagi. Menurut perkiraan penulis, potensi zakatnya bisa lebih dari 1 triliyun rupiah.

Upaya yang dilakukan BAZNAS dalam menggali potensi zakat di Kabupaten Indragiri Hilir baru sebatas bekerjasama dengan Pemerintah Daerah dalam memungut zakat penghasilan melalui Unit Pengumpul Zakat (UPZ) yang ada di Instansi-instansi Pemerintahan. Belum ada upaya untuk menggali potensi zakat yang lain selain zakat penghasilan. Di samping itu juga belum ada kerjasama dengan pihak lain seperti BUMN, BUMD, Perusahaan-perusahaan Swasta serta kalangan professional untuk menambah penerimaan zakat, infaq dan shadaqah.

Kendala yang dihadapi BAZNAS dalam upaya menggali potensi zakat di Kabupaten Indragiri Hilir antara lain : Masih ada PNS yang tidak mau dipotong gajinya, Ada perusahaan yang dulunya pernah menyalurkan zakatnya ke BAZNAS sekarang tidak lagi dikarenakan berganti kepemilikan, Masih kurangnya kesadaran masyarakat untuk membayarkan zakatnya ke BAZNAS, Kondisi geografis Kabupaten Indragiri Hilir yang sangat luas, Tidak adanya bantuan operasional dari Pemerintah Daerah, sehingga pengurus terpaksa hanya mengandalkan bagian dari amil serta Tidak adanya koordinasi dengan pihak terkait lainnya seperti Kementerian Agama, KUA, serta UPZ atau amil-amil yang ada di masjid-mesjid dan mushala.
Commented [01]: Sebaiknya memuat poin-poin SWOT secara utuh. 


\section{Daftar Pustaka}

Abdurrahman Qadir, Zakat dalam Dimensi Mahdah dan Sosial, (Jakarta: Raja Grafindo Persada, , 1988).

Abdul Aziz, Manajemen Investasi Syariah, (Bandung: Alfabeta, 2010).

Ahmad Muhammad al-'Assal dan Dr. Fathi Ahmad Abdul Karim, Sistem, Prinsip dan Tujuan Ekonomi Islam, (terj), (Bandung: Pustaka Setia, 1999).

Al-Qurtubi, al-jami' Li Ahkam Al-qur'an, Beirut Libanon, Daar el-Kutub 'Ilmiyyah 1413 H/1993M Jilid VII-VIII.

Badan Pusat Statistik Kabupaten Indragiri Hilir, Kabupaten INDRAGIRI HILIR DALAM ANGKA, 2016.

Depag RI, Al-Qur'an dan Terjemahnya. (Jakarta: CV. Indah Press, 2002).

Departemen Pendidikan Nasional, Kamus Besar Bahasa Indonesia, (Jakarta: PT Gramedia Pustaka Utama, 2008), cet. Ke-4.

Didin Hafidhuddin, Zakat dalam Perekonomian Modern, (Jakarta: Gema Insani Press, 2002).

Didin Hafidhuddin dan Hendri Tanjung, Manajemen Syariah dalam Praktik. Jakarta: Gema Insani Press, 2003.

Hasan, M. Iqbal, Pokok-pokok Materi Metodologi Penelitian dan Aplikasinya. (Jakarta: Bumi Aksara, 2002)

Ibn Hajar al-Asqalani, Fath al-Bari bi Syarh Shahih al-Bukhari, Juz, III, (Kairo: Dar al-Rayyan at-Turats, $\mathrm{tt}$ ).

Kamus Besar Bahasa Indonesia, offline 1.4

Kamus al-Munawwir, Software Al-Munawwir Translator Program, v. 1.0.0, 2010.

Kountur, Ronnhy, Metode Penelitian Untuk Penulisan Skripsi dan Thesis (Jakarta: PPM, 2004).

Lexy J. Moleong, Metodologi Penelitian Kualitatif edisi revisi cet.21, (Bandung: Remaja Rosdakarya, 2005.)

Majma Lughah al-Arabiyyah, al-Mu'jam al-Wasith, (Mesir: Daar al-Ma'arif, 1972), Juz I. 
Mahfuz Zuhdi, Masailul Fiqhiyah, (Jakarta: CV. Haji Masagung, 1993).

Muhammad Abdul Jawwad, Menjadi Manajer Sukses, Jakarta: Gema Insani, 2004.

Nur Indriantoro \& Bambang Supomo, Metodologi Penelitian Bisnis, (Yogyakarta: BPFE-Yogyakarta,2002), Cet. Ke-2.

Qardhawi, Yusuf, Fiqh al-Zakat, Muasasah al-Risalah, (Beirut: Dar al-Qalam, Cet. II, VI).

Qardhawi, Yusuf, Masykilah al-Faqr wa Kaifa 'Alajaha al-Islam, (Libanon: Darul 'Arabiyah, 1966).

Quraish Shihab, Membumikan al-Qur'an, (Fungsi dan Peran Wahyu dalam Kehidupan Masyarakat), (Bandung: Mizan, 1994).

Ridha, Rasyid, Tafsir al-Manar, (Cairo: Darul Manar, 1950)

Sabiq, Sayyid, Fiqhus Sunnah, (Bandung: PT. Al-Ma’arif, 1990).

Sofyan Assauri, Manajemen Prodsuksi dan Operasi, (Jakarta: FE-UI Jakarta, 1997), Ed. Revisi.

Undang-undang Republik Indonesia Nomor 38 tahun 1999 tentang Pengelolaan Zakat dan Keputusan Menteri Agama RI Nomor 581 tentang PelaksanaanUndang-undang Nomor 38 tahun 1999, (Jakarta: Direktorat Urusan Haji Departemen Agama RI, 1999).

Undang-undang Republik Indonesia Nomor 23 tahun 2011 tentang Perubahan atas Undang-undang Republik Indonesia Nomor 38 tahun 1999 tentang Pengelolaan Zakat.

Wardi Bachtiar, Metode Penelitian Ilmu Dakwah, (Jakarta: Logos, 1997).

http://www.dakwatuna.com/2013/04/02/30417/potensi-zakat-umat-islam-diindonesia-belum-dioptimalkan/\#ixzz454qc3jH3 diakses pada tanggal 6 April 2016.

http://www.inhilkab.go.id/index.php/en/pages/kondisi-umum, diakses pada tanggal 6 April 2016.

http://pusat.baznas.go.id/berita-utama/pemerintah-indragiri-hilir-terapkan-zakatvia-payroll-system/Skip to main content diakses pada tanggal 7 April 2016.

http://artikata.com/arti-336589-kuak.html diakses pada tanggal 6 April 2016. 
https://www.facebook.com/GudangIlmu/posts/438713016274464.\%202014

diakses pada tanggal 6 April 2016.

http://cafemotivasi.com/pengertian-potensi-diri/ diakses pada tanggal 6 April 2016.

http:/id.shvoong.com, diakses pada tanggal 9 November 2015. 